\title{
Technological Prospective Study of Green Coffee Processing
}

\author{
Marcos Lage Cajazeira Ramos ${ }^{1 *}$, Edna dos Santos Almeida ${ }^{1}$, Carlos César Ribeiro dos Santos ${ }^{1}$ \\ ${ }^{1}$ Senai Cimatec University Center; Salvador, Bahia, Brazil
}

\begin{abstract}
This article aims to identify patents referring to coffee processing and to correlate them with the exportation scenario of the processed coffee. The research relates the keywords "coffee" and "treatment" with the International Patent Codes, in the Espacenet database. The CIP A23F5/02 has predominance, with the United States figure as the largest holder (20) and Brazil with only one patent deposit. The article suggests that countries that promote research in technology become more competitive in the exportation of processed coffee, even without producing the grain. This explains the need for policies aimed at valuing research in technological innovation in the national industry.

Keywords: Export. Coffee. Treatment.

Abbreviations: CIP: International Patent Codes; CONAB: National Supply Company; MDIC: Ministry of Development, Industry and Foreign Trade; Espacenet: European Patent Office; EU: European Union; us: United States; USDA: United States Department of Agriculture; CECAFÉ: National Council of Coffee Exporters of Brazil; SEAGRI: Secretariat of Agriculture, Livestock, Irrigation, Fisheries, and Aquaculture.
\end{abstract}

\section{Introduction}

Coffee came from Africa and was introduced into Brazil in the $17^{\text {th }}$ century. Here it found favorable climatic and social conditions to make the country a reference in production. The history of coffee grain cultivation is inherent to the country's development, it was significant for the generation of financial resources, social evolution, and today it occupies second place in world wealth, second only to oil [1]. According to the National Supply Company (CONAB), Brazil stands out as the largest producer and exporter of green coffee in the world $[2,3]$.

However, some references of economic power are emerging in the world panorama, concerning the production and export of processed coffee. A study published by the Ministry of Development,

Received on 15 September 2020; revised 7 December 2020. Address for correspondence: Marcos Lage Cajazeira Ramos. Senai Cimatec University Center, Orlando Gomes Avenue, 1845 - Piatã, Salvador, Bahia, Brazil. Zip Code: 41650-010. E-mail: engmarcos.ramos@outlook.com. Article selected from VI International Symposium on Innovation and Technology (SIINTEC).

J Bioeng. Tech. Appl. Health 2021;4(1):24-29.

C 2021 by SENAI CIMATEC. All rights reserved.
Industry and Foreign Trade (MDIC) signaled that countries such as Germany, Spain, Indonesia, Italy, Mexico, and Switzerland are investing in green coffee treatment technologies [4]. The study warns about the fact that Brazil has competitive advantages compared to other countries, as it has a large and diversified coffee park, in addition to the considerable number of coffee growers who respond to stimuli in technology for production [5].

The cycle of green coffee begins in the planting of seedlings and goes to the processes that involve the harvest and ends in the drying of coffee beans, which are subsequently known as green coffee. From there, the processed coffee production cycle begins, which is set off with the change from raw (green) coffee to roasted coffee, moving through the processes of removing impurities, selection of beans before and after roasting, and finally ends with the grinding processes.

\section{Material and Methods}

The research is not linked to any educational or agrarian research body. Developed and financed by the authors themselves, the research objective was to elaborate a technological prospection study and map the patents deposited to correlate to the world panorama of processed coffee exports to 
assess which technologies and measures Brazil should take to become more competitive in the export of processed coffee.

So, a search was carried out in the database of the European Patent Office (Espacenet), using the keywords "coffee" and "treating" and the International Patent Classification (CIP). It was developed between the months of January and June of 2020 and divided into four phases: Search for Information, Treatment of Information I/ II, Representation of results and techniques to propose future scenarios.

In the first phase, it was identified that the patents of the A23F family - "Coffee; Tea; their substitutes; manufacture, preparation, or infusion thereof" and linked to patents code A23F5/00: "Coffee; Coffee substitutes; Preparations thereof"; these patents adhere to the purpose of the article. It was observed that the most frequently found CIPs were A23F5/02; A23F5/04; A23F5/10; $\mathrm{A} 23 \mathrm{~F} 5 / 16$ and AF23F5/2. However, the patents
$\mathrm{A} 23 \mathrm{~F} 5 / 04, \mathrm{~A} 23 \mathrm{~F} 5 / 16$, and A23F5/20 combined processes for removing unwanted substances. For this reason, CIP A23F5/04 was elected as the representative of this process (Figure 1).

For phase 3, the patents that relate to CIP A23F5/02 were eligible due to the resemblance with the patents that relate to codes A23F5/04 and A23F5/1. In Espacenet, the documents were select, imported with the CSVed 1.4.9 software, compiled, and exported to a Microsoft Excel table as part of the analysis phase (Figure 2).

Table 1 presents the documents found in Espacenet based on combinations of keywords and CIP, adopted by the National Institute of Intellectual Property, which could enrich the discussion about the objects of this study.

For being restricted to one process for the treatment of green coffee, the patents whose CIP code A23F5/04 and A23F5/10 directly correlate to the CIP code A23F5/02 were eligible in phase 3. This shows how it is connected to the other codes

Figure 1. The first and the second phase of the methodological flow.

\begin{tabular}{|c|c|}
\hline 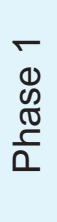 & $\begin{array}{l}\text { Search for information } \\
\text { - Search option: "Advanced Search". } \\
\text { - Use of the keywords: "coffee" and "treating" in the "title" and "summary" fields. } \\
\text { - Identification of patents in the A23F family. } \\
\text { - Adoption of patents linked to code A23F5/00. }\end{array}$ \\
\hline 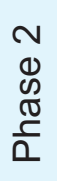 & $\begin{array}{l}\text { Treatment of information I } \\
\text { - Selection of patents A23F5/02, A23F5/04 and A23F5/10 due to their relevance. } \\
\text { - Use of the keywords: "coffee" and "treating" correlating with the patents found. } \\
\text { - Making a table with data obtained (Table 1). }\end{array}$ \\
\hline
\end{tabular}

Figure 2. The third and the fourth phase of the methodological flow.

\begin{tabular}{|c|c|}
\hline $\begin{array}{l}m \\
\stackrel{1}{\infty} \\
\mathbb{0} \\
\frac{c}{\square}\end{array}$ & $\begin{array}{l}\text { Treatment of information II } \\
\text { - Exclusion of patent documents belonging to the same family. } \\
\text { - Selected the patent code A23F5/02 as the focus of the objective. } \\
\text { - Choose of the CSVed } 1.4 .9 \text { software to compile the information. }\end{array}$ \\
\hline 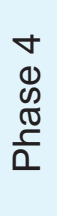 & $\begin{array}{l}\text { Representation of results and techniques for reflection on the future } \\
\text { - Import of document information citing patent A23F5/02 to CSVed 1.4.9. } \\
\text { - Do the preview and editing of the table proposed by the software. } \\
\text { - Export the table to Microsoft Excel. } \\
\text { - Editing and analysis of data relevant to the topic. }\end{array}$ \\
\hline
\end{tabular}


Table 1. Search for patents by patents and code (CIP).

\begin{tabular}{cccccc}
\hline Coffee & Treating & A23F5/02 & A23F5/04 & A23F5/10 & Total \\
\hline$*$ & & & & & 10.000 \\
$*$ & $*$ & & & & 1.015 \\
$*$ & $*$ & $*$ & & & 64 \\
$*$ & $*$ & & $*$ & $*$ & 46 \\
$*$ & & & & $*$ & 27 \\
$*$ & $*$ & $*$ & $*$ & & 5 \\
\hline
\end{tabular}

related to the treatment of green coffee beans (Figure 3).

\section{Results and Discussion}

During the research, the CIP most found was code A23F5 / 02, which refers to the process of green coffee (coffee in its post-harvest state) in general and its preparations. Then the codes for the removal and treatment of impurities and residues, whose codes are $\mathrm{A} 23 \mathrm{~F} 5 / 04, \mathrm{~A} 23 \mathrm{~F} 5 / 16$, and A23F5/20. Finally, with 5 citations, the code A23F5 / 08, which refers to coffee grinding methods.
Patent filings related to the treatment of green coffee dated since 1912 had significant growth in the last two decades, with the years 2014 and 2015 standing out with 4 filings. Brazil is the author of only one deposit, dated in 2007. The United States (US) stands out, with 20. The European Union (EU) emerges with 17. In Asia, Korea and Japan are the leaders, with 4 and 16 patents respectively (Graph 1).

The depositor with the highest number of patents for the treatment of green coffee is Nestlé S.A., a Swiss company, responsible for 5 patents.

The American Verdurin Company and the Japanese Suntory LTD follow right behind (Graph 2).

Figure 3. Distribution of patents related to coffee processing by codes.

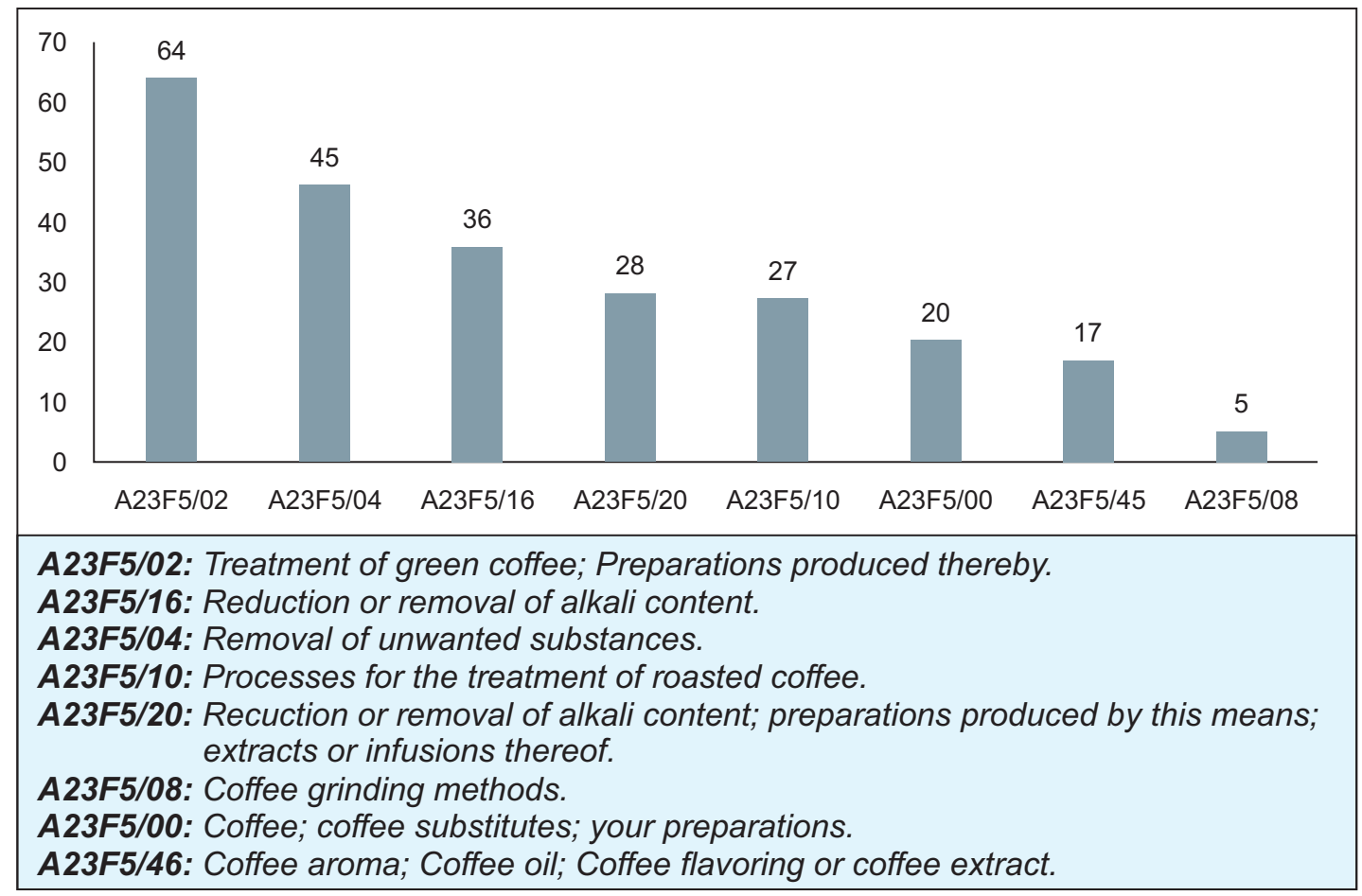


Graph 1. Countries with the highest number of patent filings.

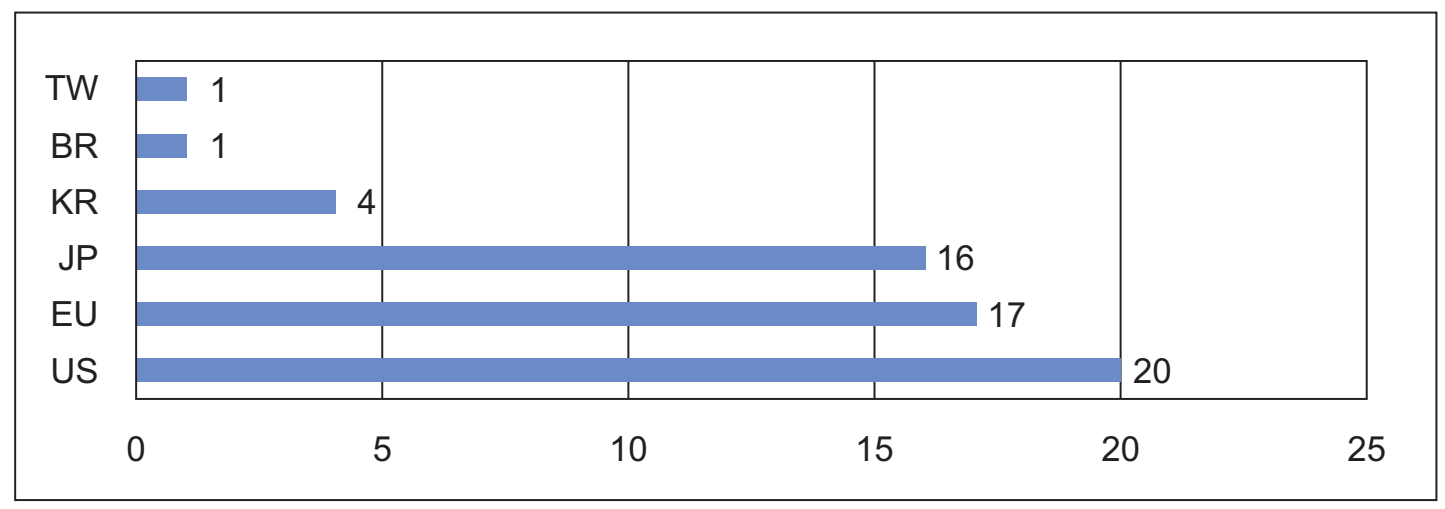

TW: Taiwan; BR: Brazil; KR: Korea; JP: Japan; EU: European Union; US: United States.

According to the United States Department of Agriculture (USDA) in 2020, Brazil is the largest coffee producer in the world (Table 2) [6,7].

The country's leadership is also seen in the ranking of green coffee exports (Table 3) [6,7].

However, the country is limited to the supply of raw material (green coffee) to exporters of processed coffee [8]. In this second cycle of coffee, some countries focus on investing in research and technology to add value to the product, according to the ranking of processed coffee exporters. In this ranking, it is possible to identify the importance of the company Nestlé SA patent filings to the relevance of Switzerland in the exportation of the processed coffee world scenario, a country that does not possess appropriate climatologic and geographic characteristics to cultivate the bean. (Table 4) [6,7].
According to the study, the focus of these countries is on technologies aimed at the selection of grains and removal of unwanted substances, CIP A23F5/04, both for green coffee and for subsequent processes of changes in the impurities of the grain after roasting or grinding. This observation serves as a guide for the use of policies to encourage research and technology development that can change the production criteria from a focus on volume to a focus on quality and identity [5]. A strategy that has to be initiated by cooperatives or associations with administrative and technological support to producers, and support by the local government $[9,10]$. The National Council of Coffee Exporters of Brazil (CECAFÉ), released the ranking of the destination of Brazilian green coffee (Graph 3), it is possible to noticethepresenceofthecountriesthathold thelargest

Graph 2. Companies responsible for the largest number of patent filings.

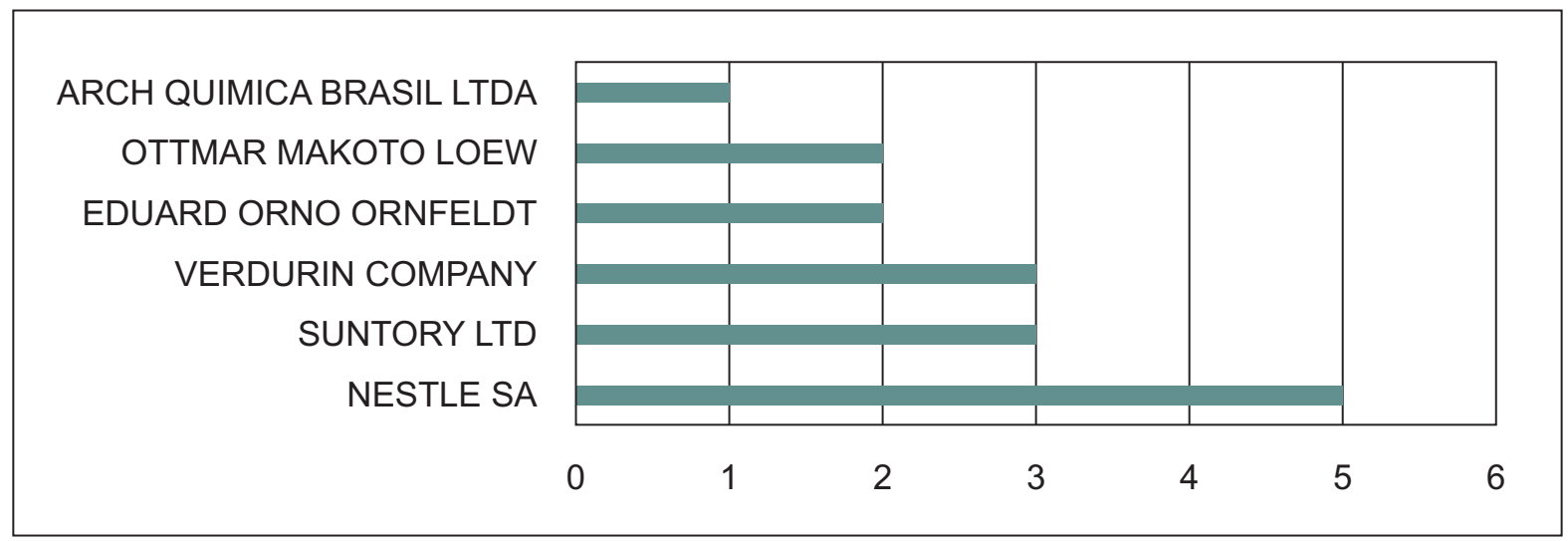


Table 2. The highest coffee producer in the world.

\begin{tabular}{clcc}
\hline Position & Country & 2019/20 Ton-60kg Bag & 2020/21 Ton-60kg Bag \\
\hline 1 & Brazil & 59,300 & 67,900 \\
2 & Vietnam & 31,300 & 30,200 \\
3 & Colombia & 13,800 & 14,100 \\
4 & Indonesia & 10,700 & 10,300 \\
5 & Ethiopia & 7,450 & 7,500 \\
6 & Honduras & 5,600 & 6,125 \\
7 & India & 4,890 & 5,310 \\
\hline
\end{tabular}

Table 3. The highest green coffee exporters in the world.

\begin{tabular}{clcc}
\hline Position & Country & $\mathbf{2 0 1 9 / 2 0}$ Ton-60kg Bag & 2020/21 Ton-60kg Bag \\
\hline 1 & Brazil & 32,700 & 37,000 \\
2 & Vietnam & 24,000 & 24,000 \\
3 & Colombia & 12,000 & 12,400 \\
4 & Indonesia & 6,096 & 5,900 \\
5 & Honduras & 5,500 & 5,575 \\
6 & Uganda & 4,000 & 4,500 \\
7 & Peru & 4,360 & 4,265 \\
\hline
\end{tabular}

Table 4. The highest exporters of processed coffee in the world.

\begin{tabular}{clcc}
\hline Position & Country & $\mathbf{2 0 1 9 / 2 0}$ Ton-60kg Bag & $\mathbf{2 0 2 0 / 2 1}$ Ton-60kg Bag \\
\hline 1 & Europe & 1,775 & 1,500 \\
2 & Switzerland & 1,425 & 1,400 \\
3 & Vietnam & 550 & 550 \\
4 & Colombia & 120 & 300 \\
5 & Mexico & 230 & 230 \\
6 & Indonesia & 56 & 50 \\
7 & China & 25 & 25 \\
8 & Brazil & 24 & 24 \\
\hline
\end{tabular}

number of patent deposits related to the processing of green coffee, previously shown in Graph 1 . The analysis corroborates with the Secretariat of Agriculture, Livestock, Irrigation, Fisheries and Aquaculture (SEAGRI), in a 2011 report, where the authors state that most producers, especially small ones, do not use the most modern technologies available for coffee growing, especially about coffee processing [11].

Although the country stands out as the largest coffee producer in the world, the number of patents related to the treatment of green coffee reflects the world panorama of processed coffee. In Brazil, the coffee is exported and used as an input for the expansion of the industrial sector in other countries, which in some cases, do not even have a geographical and climatic condition for planting. This reinforces the thesis that there are ways to add value to green coffee and have to be adopted in small and medium coffee industries in the country. Reference countries in technology and innovation invest in research to add value to the product. The 
Graph 3. The highest destinations for the Brazilian green coffee bean.

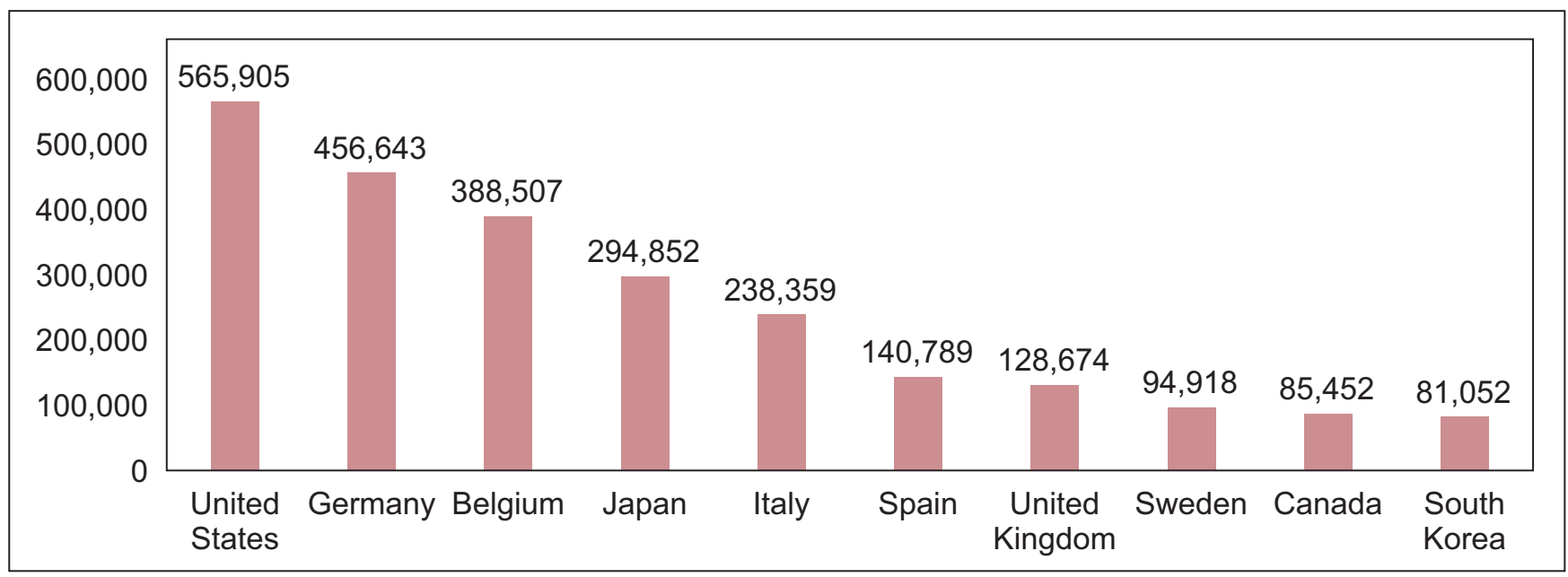

United States, for example, has 20 patents filed. Brazil, despite being the world's largest coffee producer, has only one deposit, made by a chemicals company in the biotechnological industry.

Thus, it is possible to affirm that Brazil has the potential to figure as an important exporter of processed coffee in the world. However, for this panorama to become a reality Brazil must reflect countries that invest in technology and research, such as the countries with the largest numbers of patent filings. There is a favorable, broad market for the country, which can boost the generation of jobs and strengthen national technology while favoring the Brazilian economy.

\section{References}

1. Ferrão RG et al. Café Conilon. Vitória, ES: Incaper, 2016, 2017.

2. CONAB, Companhia Nacional de Abastecimento. Acompanhamento da safra brasileira. 2018.

3. Organização Internacional do Café - OIC. Relatório sobre o mercado de café: março 2018. São Paulo: OIC, 2018. 6p. Available in: <http://consorciopesquisacafe.com.br/ arquivos/consorcio/publicacoes_tecnicas/relatorio_oic_ marco_2018.pdf $>$. Accessed in: May 20, 2020.
4. Sório A (coord). Reposicionamento estratégico das indústrias processadoras de café do Brasil: propostas para sistematização de políticas públicas e estratégias de negócio. Passo Fundo: Méritos, 2015.

5. ABICS. Ameaçada a liderança mundial do Brasil nas exportações de café solúvel. 2018. Available in: <http:// www.abics.com.br/ameacada-alideranca-mundial-dobrasil-nas-exportacoes-de-cafe-soluvel/>. Accessed in: 08 June. 2020.

6. United States Department of Agriculture. Coffee: world markets and trade. 2020.

7. ABICS. Café solúvel cria marca setorial para mercados nacional e internacional. 2019. Available in: <https:// www.abics.com.br/noticia.php?noticia $=156 \&$ cafe_ soluvel_cria_marca_setorial_para_mercados_ nacional_e internacional $>$. Accessed in: 08 July. 2020.

8. Franck AGS et al. Análise da competitividade do mercado exportador brasileiro de café. Desafio Online, v. 4, n. 3, p. 1-21, 2016.

9. Conseliho dos Exportadores de Café do Brasil. Relatório de exportações. Available in: <https://www. cecafe.com.br/publicacoes/relatorio-de-exportacoes/>. Accessed in: 12 July 2020.

10. Franco ME et al. Cenário da tecnologia de informação na gestão da produção de café no sul de Minas Gerais. Interações (Campo Grande) 2018;19(2):373-385.

11. SEAGRI. Secretaria da Agricultura, Irrigação e Reforma Agrária. Diagnóstico e propostas para a cadeia produtiva do café da Bahia. 40 p il. Bahia, 2011. 